\title{
Trade-offs in linking adaptation and mitigation in the forests of the Congo Basin
}

\author{
Roger Few ${ }^{1} \cdot$ Adrian Martin $^{1} \cdot$ Nicole Gross-Camp ${ }^{1}$
}

Received: 23 July 2015/Accepted: 6 November 2016/Published online: 21 November 2016

(c) The Author(s) 2016. This article is published with open access at Springerlink.com

\begin{abstract}
Recent discussions on forests and climate change have highlighted the potential for conservation of tropical forests to contribute synergistically to both mitigation (reducing emissions of greenhouse gases) and adaptation (increasing capacity to cope with changing climate conditions). Key mechanisms through which adaptive advantages might be gained include the potential for forest resources to support livelihoods in the context of climatic strains on agriculture and the protection that intact forest ecosystems might provide against landslides, flash floods and other hazards related to extreme weather. This paper presents findings from field research with forest communities in three areas of the Congo Basin in Central Africa, in which the adaptive role and potential of forests in these respects is critically analysed. The investigation was carried out through a combination of structured and semi-structured qualitative techniques within six villages in Cameroon, Equatorial Guinea and Rwanda. The findings of the research highlight the need to understand both the limits of synergy, and the constraints and trade-offs for rural livelihoods that may be associated with a forest conservation agenda driven by the additional impetus of carbon sequestration. The search for synergy may be conceptually laudable, but if forest management actions do not take account
\end{abstract}

Editor: James Ford.

Roger Few

R.Few@uea.ac.uk

Adrian Martin

Adrian.Martin@uea.ac.uk

Nicole Gross-Camp

N.Gross-Camp@uea.ac.uk

1 School of International Development, University of East Anglia, Norwich Research Park, Norwich NR4 7TJ, UK of on-the-ground contexts of constraints and social trade-offs then the result of those actions risks undermining wider livelihood resilience.

Keywords Adaptation - Forests - Climate change Trade-offs · Livelihoods · Congo Basin

\section{Introduction}

Recent discussions on forests and climate change have highlighted a potential for efforts to conserve tropical forests to integrate mitigation and adaptation goals (Locatelli et al. 2015; Kongsager and Corbera 2015). The carbon storage function of forests is a central pillar of the climate change mitigation agenda, as demonstrated since 2008 in the high profile of REDD (Reducing Emissions from Deforestation and forest Degradation) activities in developing countries, and related carbon management initiatives. Perhaps less firmly established in climate change discourse is the argument that forests can provide a significant contribution to climate change adaptation for local populations, although momentum behind this perspective among forest researchers has been growing in recent years (Locatelli et al. 2010; Nkem et al. 2013; Somorin et al. 2016). It is both important and timely for researchers from broader development fields to contribute to this debate. This paper presents findings from field research with forest communities in three areas of the Congo Basin in Central Africa. The objective is to critically analyse the adaptive role and potential of forests, particularly through consideration of livelihood trade-offs, as input to debate on the possible synergy between adaptation and mitigation in forest management. It presents both evidence for the adaptation potential of tropical forests and evidence to 
caution against overly optimistic assumptions that might downplay the trade-offs for livelihood resilience associated with a mitigation agenda.

Recent global agreement to try to limit global average temperature increase to within 2 degrees above pre-industrial levels will require a highly ambitious mitigation effort (Frame et al. 2014; Anderson 2015), and it is extremely likely that forest-based interventions will continue to be relied on to play a key part. Tropical and sub-tropical forests hold around 55\% of global forest carbon stocks, with more than half of this being in biomass (Parrotta et al. 2012). Forest loss and degradation constitute the second largest anthropogenic source of carbon dioxide, estimated by Harris et al. (2012) at $7-14 \%$ of global emissions. The influential review of the economics of climate change by Stern (2007) recognised deforestation as a comparatively low-hanging fruit for climate mitigation owing to its low unit costs.

The idea that low-cost forest-based mitigation could also bring co-benefits to local communities, including greater livelihood resilience, was prominent in the Bali Action Plan agreed at the 13th Conference of Parties of the United Nations Framework Convention on Climate Change (UNFCCC) in December 2007. This connects with an increasingly popular view that forest-based mitigation can provide 'win-win' outcomes that show synergies between mitigation and adaptation: i.e. simultaneously reducing net emissions of greenhouse gases and increasing people's capacity to cope with changing climate conditions. This reasoning especially applies if adaption is considered broadly, as activity that renders livelihoods more resilient. Resilience, in this sense, can be understood as the capacity both to maintain functions in the face of external stresses and to adapt to change (Nelson 2011; Saxena et al. 2016). There are several causal pathways by which forest conservation and enhancement is thought to contribute to resilience, commonly articulated through the concept of ecosystem services (ecosystem services refer to the benefits people derive from ecosystems). Firstly, there is increasingly strong evidence that biodiversity supports not only ecosystem productivity but also stability of ecosystem functions, making human use of ecosystems for agriculture and fisheries better able to absorb climate shocks (Cardinale et al. 2012). Secondly, there is growing acknowledgement that forests make more direct and substantial contributions to human food security through, e.g. wild harvests and agroforestry systems, and serve as safety nets at times when extreme weather reduces farmed crops (Vira et al. 2015). Thirdly, forest cover can help to reduce the occurrence of climaterelated hazards such as landslides, floods and droughts (Bele et al. 2013; Robledo et al. 2012; Wahlstrom 2015).

The prospect of designing forest policies and interventions that integrate mitigation and adaptation outcomes is highly attractive. However, whilst we highlight possibilities for such integration we argue that progress towards this will require full attention to a range of trade-offs. We have learnt that 'win-win' outcomes are rarely guaranteed, even when they appear plausible in theory (McShane et al. 2011). Indeed trade-offs, not synergies, are the norm for ecosystem management outcomes and our understanding of why this is so has been enhanced by critical thinking around ecosystem services (Bennett et al. 2009; Howe et al. 2009). Firstly, ecological trade-offs can be said to occur where ecosystem management enhances one or more ecosystem service at the expense of reducing at least one other service (Rodríguez et al. 2006; d'Amato et al. 2011). Most commonly, such ecological trade-offs occur between demand for ecosystems to produce food and support livelihoods, and demands for them to produce regulatory services (Raudsepp-Hearne et al. 2010). Secondly, tradeoffs have a social dimension, where the interests of some stakeholders conflict with the well-being of others (Daw et al. 2015). This can be closely linked to ecological tradeoffs, e.g. where one stakeholder prefers management of forests to maximise biodiversity whilst another prefers management to maximise forest food availability. But it can also occur where management changes access regimes, such that the capture of an ecosystem service by one stakeholder group, reduces access for other stakeholders. Thus ecosystem service trade-offs are ultimately linked to power relations among stakeholders (Howe et al. 2009; Sikor 2013).

Spatial and temporal dimensions cut across these ecological and social dimensions of trade-offs (Rodríguez et al. 2006) and are particularly relevant to mitigation and adaptation (Harvey et al. 2014). For example extensification of cash crop production might improve local economic livelihoods and thereby ability to cope with weather variability in the short term but may undermine mitigation of global climate change. More generally, trade-offs between food production and climate regulation commonly involve conflict between local interests (both short-term subsistence and longer-term adaptation) and global interests (both climate regulation and biodiversity conservation) (Tol 2005; Ibarra et al. 2011; Sikor 2013). This is not to say that mitigation and adaptation, and global and local interests, are necessarily incompatible-but to recognise that the existence of trade-offs cannot be overlooked and should be the subject of analysis.

The findings reported in this paper provide additional empirical evidence to feed into this debate. They are based on case study research conducted in six communities within and close to forest environments in three areas of the Congo Basin. The next section introduces the sites and the methods of data collection. This is followed by a brief note on local perceptions of the climate-related stresses 


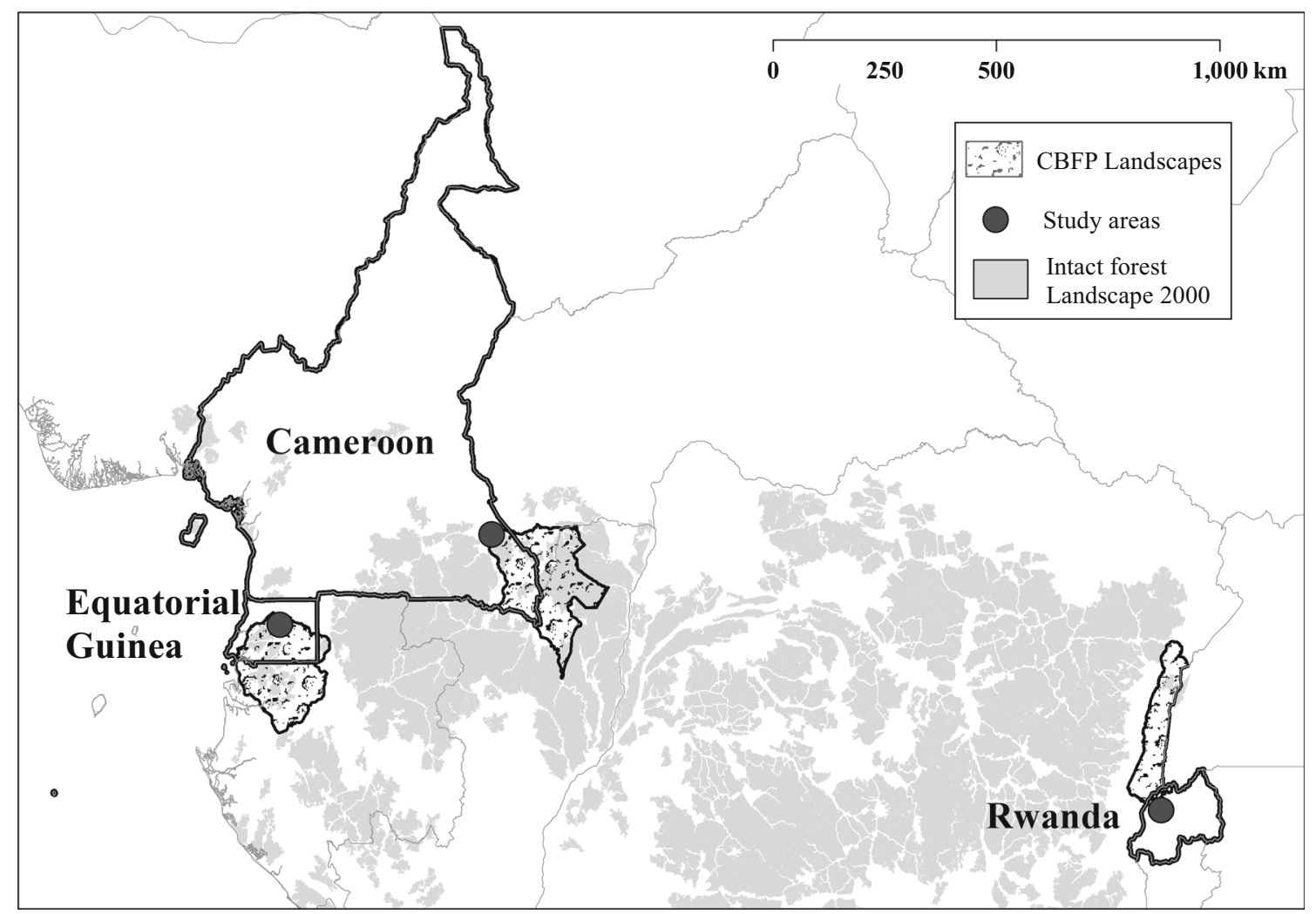

Fig. 1 Location of the study areas and the corresponding CBFP regional landscapes

experienced in the sites. Two major sections then follow, discussing the role that forests play in supporting livelihoods and well-being, and the actual and potential tradeoffs for local people associated with forest conservation and/or reforestation. The concluding section draws out implications of the empirical findings for mitigationadaptation integration debate.

\section{Case studies context and methodology}

The research was undertaken from July 2012 to March 2013 in a total of six villages in three countries-Cameroon, Equatorial Guinea and Rwanda. The research was designed to help describe how forest communities are experiencing and adapting to environmental change, and the role that forest resources and environmental management policies play in terms of people's livelihoods. It was part of a wider project, Climate Change and Forests in the Congo Basin (COBAM), aimed at supporting policy and practice in adaptation and mitigation in the forests of Central Africa.

The study areas in each country (see Fig. 1) lie within one of the Congo Basin Forest Partnership 'landscapes' prioritised under the Congo Basin Ecosystems Conservation Support Programme (PACEBCo): the Tri-National de la
Sangha landscape for the area in south-east Cameroon, the Monte Alen-Mont Cristal landscape in central Equatorial Guinea, and the Virungas in north-west Rwanda. For each landscape, baseline assessment studies undertaken at an earlier phase of the COBAM project were used to select two sites for detailed research. These villages were Djalobekoue and Mang (Cameroon), Atom and Kukumankok (Equatorial Guinea), and Kamiro and Masasa (Rwanda).

Table 1 provides some brief information on the study sites and their contexts, which vary considerably, not least in terms of the systems applied for forest management. For example, at the Rwanda site, forest conservation is governed under a state-run Protected Area, whilst community forest management formed part of the governance mix at the Cameroon sites in a country preparing forests for REDD+ (an extension to the aims of REDD that highlights the role of conservation, sustainable management of forests and enhancement of forest carbon stocks) under the UN REDD readiness programme. This diversity of contexts and interventions is important for the purposes of this paper. Our ambition here is not to describe or predict the outcomes of a particular intervention, but rather to highlight the way in which trade-offs exist across a wide-range of contexts. The observation of such trade-offs across different contexts strengthens confidence that they are an intrinsic effect of intervention in this field. 
Table 1 Study sites and the local/national context

\begin{tabular}{lll}
\hline Country Sites & Land/forest management context
\end{tabular}

Cameroon Djalobekue and Mang are located 7 and $40 \mathrm{~km}$, respectively, from the main town of Yokadouma in south-east Cameroon. The village economies are dominated by agricultural production for subsistence and cash crops, with cassava, plantain, corn, coffee and cocoa as principal crops (Devisscher et al. 2013)

Equatorial Atom and Kukumankok are located approximately $140 \mathrm{~km}$ by Guinea road from the coastal port of Bata in Equatorial Guinea. Economic livelihoods are principally agricultural, including slash-and-burn production systems for subsistence and cash crops, including cassava, plantain, groundnut and sugar cane (Pavageau et al. 2013a)

Rwanda Kamiro and Masasa lie adjacent to the Volcanoes National Park, about $120 \mathrm{~km}$ north-west of Kigali by road. Agriculture is the main livelihood in these communities, with production of crops such as potatoes, maize, sorghum, peas, wheat and beans, together with tea, pyrethrum and other cash crops (Pavageau et al. 2013b)

The south-east of Cameroon is one of the most sparsely populated areas of the country, with a population density of less than 5 people per $\mathrm{km}^{2}$. Secondary forest and clearings for cash crops start at the periphery of the study villages, with primary forest located several kilometres from the village centre. Villagers enter the forest for hunting and small-scale extractive use of non-timber forest products (NTFPs). Industrial logging concessions and mineral extraction occur in the wider area around the Cameroon sites (Devisscher et al. 2013). Mang shares the 5500 ha Mpiemog Community Forest with three additional villages, whereas Djalobekue is among seven villages sharing the management of the Morikoulaye Community Forest (5000 ha). Cameroon has promoted community forests and more recently REDD+ as a means to assist in communities' ability to adapt to climate change (Dkamela 2011). Community forests have been legally recognised in Cameroon since 1994 but remain largely managed de facto by village or clan leaders

Forest cover is relatively high in Equatorial Guinea with relatively low deforestation pressures and a population density of 16 people per $\mathrm{km}^{2}$ (Mugnier Martinez-Plaza (2009). Secondary forest and clearings for cash crops start at the periphery of the study villages, with primary forest located several kilometres from the village centre. Villagers enter the forest for hunting and small-scale extractive use of non-timber forest products (NTFPs). There is a history of logging in the forests around the Equatorial Guinea sites (Pavageau et al. 2013a). The government of Equatorial Guinea has been developing mechanisms to allow communities to benefit from the protection of carbon through for example REDD+ finance and local forest management. Although the country recognises communities' rights to manage forests traditionally associated with their villages, only a small number of communities are in possession of land certificates (GoEG 1997a, 1997b; Nguema and Pavageau 2013)

Rwanda is the most densely populated of our study sites with an average density of 300 people per $\mathrm{km}^{2}$. At the study sites the landscape is predominantly agricultural, with fields extending up to the boundary of the Volcanoes National Park.

Agricultural plots tend to be small, on average between 0.25 and 0.8 ha, and fuelwood is collected predominantly from plantations or private woodlots. Land titles are registered at the national level, creating a more tightly formalised system than is present in the other two countries. Rwanda has integrated forest and land management into its institutional architecture on climate change mitigation and adaptation, spurred by adoption of a National Adaptation Programme of Action (RoR 2006, 2011) and a Green Growth and Climate Resilience strategy (RoR 2011). Adaptation interventions have focussed particularly on projects to combat soil erosion and landslides as well as the development of alternative energy sources to wood. Gebauer and Doevenspeck (2015) argue that the climate risk reduction agenda has also legitimised contentious cases of resettlement of communities from landslide/flood hazard zones 
In each country, field research was conducted in collaboration with COBAM local partners ROSE (a network of NGOs in southeastern Cameroon) in Cameroon, INDEFOR-AP (National Institute for Forest Development and Protected Areas System Management) in Equatorial Guinea, and ARECO-RWANDA NZIZA (Association of Rwandan Ecologists) in Rwanda. The methodology for this phase of the research was a combination of structured and semi-structured qualitative techniques, conducted in the local languages (Mbimou, Fang and Kinyarwanda) and subsequently translated. ${ }^{1}$

Research activities in each village commenced with a group interview with community leaders to identify major environmental changes/events and their consequences, and to understand local patterns and how forest was managed locally.

Subsequently, 20 households were selected at random in each of the six villages, with interviews conducted with one or more heads of household. Because the Cameroon villages contained residents of the Baka ethnic minority group, we stratified the sample to include five Baka households. The interviews were structured in the first stage to track household social and economic trajectories, perceptions of environmental change, and changes in access to resources. This was followed by semi-structured, second-stage discussions designed to explore householders' perceptions of major livelihood threats and possibilities for adaptive action, and broader perspectives on forest and land use management.

In the sections that follow we explore some of the findings from this data, across the study sites and the 126 household and group interviews. It is recognised that the qualitative focus of the research did not enable the team to survey a statistically representative sample of the population of each village, nor provide for a rigorous social stratification of data. However, the team believes that the complex nature of the topic and the process of discussion that it required with interviewees made it difficult to justify use of extensive survey techniques. It is through intensive qualitative work that the subtleties and trade-offs of forest-based adaptation can best be explored; and it is the perspectives that emerge from people's individual testimonies that are most illustrative and informative at this stage in assessing the potential of mitigation — adaptation synergies on the ground.

\section{A note on climatic stresses}

As part of the research we initially analysed how villagers in the six sites perceive their vulnerability to climate stresses arising from climate variability and change.

\footnotetext{
1 The research team has endeavoured to ensure that quotes provided in the paper are as faithful as possible to the original words of the interviewee.
}

Understanding perceptions of climate stresses is key to understanding both how people respond (or not) in an adaptive sense and their perspectives on the priorities and appropriate modes for intervention (Vedwan and Rhoades 2001). Though there is not the space in this paper to detail the findings on perceptions of climate stresses, it is useful to note briefly the key points raised (for more detail please see Few et al. (2014).

In all six villages heavy rains, flooding and high winds were commonly raised as priority 'environmental problems', but the most consistently raised issue in group and household interviews was an increasing unpredictability of rainfall and shifting patterns of seasonality (expressed by $90 \%$ of interviewed households in Cameroon, $60 \%$ in Rwanda and $83 \%$ in Equatorial Guinea). Soil erosion associated with heavy rains was considered a particular problem in the Rwandan sites, with instances of gullying recently taking place in the vicinity of the villages on the lower flanks of the volcanoes.

Villagers described that the unpredictability of the rains has consequences that included disruption to planting and other seasonally timed production activities, ecological impacts on crop disease prevalence and, ultimately, reduced crop yields. Production losses have wider repercussions for human well-being because of their impact on subsistence and income. Households suffering from crop disease in Cameroon stated that the loss of income led to a need to reduce expenditures on household items and children's school fees. It is important to recognise the way that climatic impact on farming can have a cascading effect on many other aspects of people's livelihood assets.

Of course, climatic stress on livelihoods does not occur in isolation from wider socio-environmental pressures and dynamics. The impacts identified by villagers in the six sites were also associated directly and indirectly with other factors. In Equatorial Guinea, for example, an environmental change factor of widespread concern was a growing incidence of crop raiding by wild animals, which was already said to be depleting crop production. This exacerbated the effects of climatic stresses on crop production. In Rwanda, a key exacerbating socio-political factor was felt to be policy constraints on land use. Policies on crop planting in Rwanda have exerted tight controls on what can be grown by farmers. Both these issues are explored in greater depth later in the paper.

\section{Adaptation via mitigation: the potential}

Given the problems and adaptive constraints noted above, a key objective of the research was to gauge the extent to which people are, or could be, drawing on forest resources as an adaptation resource. This links to the ideas of 
deriving adaptive co-benefits from mitigation via carbon management. However, in order to understand this potential synergy between adaptation and mitigation in a humid tropical environment, the role and potential of arboreal landscapes to contribute to livelihood support and resilience has to be critically analysed. This includes giving voice to the priorities and concerns of local communities.

Through the evidence of people's testimonies, we now examine in more detail how communities can derive benefit for livelihood resources from forest landscapes (the surrounding forests and standing trees on their land), together with the constraints on these benefits. In the section that follows, we then concentrate on the possible tradeoffs.

\section{Forests as a source of income and subsistence (ordinary use)}

Utilisation of products from the forest is woven into the traditions of all these settled villages, although it should also be noted that both availability of forest resources and level of dependence on them are dynamic conditions. In Cameroon 25 of the households reported deriving income from the sale of NTFPs collected from the forest including bushmeat, bush mango, fish, koko, caterpillars, djembe and djansang. In Equatorial Guinea, 39 households described the collection and sale of forest items in particular bushmeat, fish, palm oil, wild fruits and melongo (basket weaving material), and access to reliable water sources was also seen as a key benefit of the forests that surround the villages. For example, in Atom one householder (Atom 09) stated:

Yes I am interested [in protecting the forest], because

I completely depend on forests for food and for

earning money, medicine, drinking water, everything

is found in the forest, therefore I want to it to stay.

In the Rwandan sites, the extraction of NTFPs from the park appeared to be at a low level though there was evidence that people did still occasionally enter the forest to collect resources like bamboo to sell. Discussions in one village suggested that some people also regularly accessed the park to collect firewood and bushmeat, and collection of water from watercourses in the park was undertaken by some households, particularly during the dry season. Moreover, many of the interviewed households were beekeepers and preferred to set their hives near the park boundary so that the bees could access the forest flowers.

Medicinal plant use occurs in all countries-reported by 17 households in Cameroon, 18 in Rwanda and 8 in Equatorial Guinea-and most of these plants can be sourced from the forest. However, many households in
Rwanda indicated that the plants are cultivated around the home and less relied upon now that access to formal health care has improved.

In Cameroon, 35 households stated that there had been a decrease in NTFP availability, generally attributed to clearing of forest for new agricultural land and concurrent increase in demand for sale of such products. In Equatorial Guinea, there was a balance between those who perceived that NTFP availability was decreasing or becoming highly variable and those who felt there had been no change. Four households indicated that the distance travelled to access NTFPs had increased and five indicated that they felt the reduction in access was due to deforestation and competition with forest animals.

A total of 32 households in Cameroon and 22 households in Equatorial Guinea described bushmeat access as declining, with most who gave a reason attributing the decline to an increase in hunting activities, including greater use of guns and increased hunting for sale rather than subsistence. Discussions with villagers indicated that a recent change in hunting practices may have taken place, with fewer traps now set in the primary forest and more in the cultivated, secondary forest. This was also linked to the problem of crop raiding, with traps set to reduce crop losses doubling up as a source of bushmeat.

\section{Forests as an alternative source of resources (extraordinary use)}

Some of the arguments around an adaptation value of forest management are that it provides an alternative source of resources or potential safety net (Nkem et al. 2010, Wunder et al. 2014, Vira et al. 2015). Only one household explicitly indicated that access to forest products currently acts as a kind of insurance against times when regular sources of incomes are lean, although another in Rwanda referred to a past safety net function of 'collecting bamboo' from the forest (Masasa 02). However, other forms of extraordinary use were also identified by interviewees.

In Equatorial Guinea, one of the key assets that a forested landscape was seen to bring was access to land. With a tradition of shifting cultivation, villagers viewed the forest as a resource from which one could obtain new farming land. In the words of one interviewee: 'We still have a lot of forests spare.... you can go to another place' (Atom 05). It seems that most commonly farmland was inherited but if necessary people cleared and claimed new plots in previously unfarmed areas of forest. Similarly, in the Cameroon sites, a commonly stated response to problems of declining crop productivity and/or spread of crop diseases was to abandon the plot and clear elsewhere in the forest. The irony in this sense is that the livelihood support (adaptation) value of the forest is the existence of unfarmed 
land-but in bringing that support into operation the result is deforestation.

One other way in which the forest acts an alternative resource is provision of space for isolation and refuge. Animal diseases, in particular for chickens and pigs, were identified as a problem of increasing importance in Cameroon. One potential response identified by most households was to send the animals to the forest for protection during epidemics. Two households from Masasa (Rwanda) and two from Mang (Cameroon) spoke of using the forest as a place to seek safety during civil unrest and conflict.

\section{Trees on farms}

To some extent, communities in the study villages had undertaken tree planting in and around their villages, which can be expressed as a 'forest management' measure to provide hazard protection, reduce land degradation and crop loss, and provide a source of fuelwood.

The effect of standing trees in buffering against wind and extreme temperature hazards was raised in the Equatorial Guinea sites, while in Rwanda a major reason for planting trees was to reduce gullying and soil erosion caused by intense rains and flash floods. In Cameroon, three villagers from Mang indicated that they had recently stopped felling trees on their cacao plots as a measure to prevent damage to cacao from exposure to increasingly intense sunshine. The potential to develop agroforestry further in the area was discussed during interviews, although households commonly expressed uncertainty about skills for successful tree cultivation and the compatibility of the trees with their crops, as well as issues of ownership if tree planting were to be supported externally.

Planting of trees for fuelwood was also a common motivation in the Rwandan sites. However, for some households this had not offset a reported decline in firewood access, and some stated that they were constrained in tree planting by labour resources. A contrasting three households reported an increase in firewood availability because of success in production of trees on their land. One household (Masasa 02) reported: 'Nowadays, no one is allowed to enter into the park for collecting firewood. We don't have fire problems because we planted our own woodlot.'

\section{Adaptation via mitigation: the trade-offs}

In discussions with villagers, it was clear that most people derived positive benefit from forest resources in their surrounding environment. But it was also clear that the existence of the forest and the existence or potential existence of forest conservation practices were perceived to have negative implications for various aspects of people's livelihoods. We argue that it is vital for researchers to explore the negative, as well as positive, effects arising from the range of forest management interventions that are broadly intended to conserve trees and retain or enhance stocks of forest carbon. Here, we present these as a series of trade-offs for local people arising from maintenance and/or increase in forest coverage. In doing so, we refer to the conceptualisation of trade-offs as having ecological, social and spatial-temporal dimensions.

\section{Trade-off 1: forest proximity versus crop raiding}

For households deriving hazard protection, resources and income sources from forested environments, the spatial proximity of the forest to their homes and properties is evidently an advantage. Yet to varying degrees, it exposes households to contact with wildlife. In Kukumankok, there was a high degree of concern about danger to humans from forest animals coming into settled clearings, particularly elephants and snakes, and some households in Atom described the killing of livestock by forest-dwelling carnivores. But it was crop raiding by herbivores that was most commonly regarded as a problem across the three countries.

Crop raiding was identified as a high priority issue by 17 of the interviewed households in Cameroon, 27 in Equatorial Guinea and 31 in Rwanda (i.e. over $60 \%$ of all households in the study). The animals identified as raiding crops in Cameroon include hedgehogs, squirrels, rats, monkeys, birds (parrots and partridges), porcupines and duiker.

In the Equatorial Guinea villages, though crop raiding was not a new issue, there was some indication that the problem is increasing. Two households in Kukumankok reported changing the types of crops they grow in order to reduce the problem, with one ceasing to plant yams and bananas for this reason, and the other interviewee indicating that she only grew cassava to reduce problems with wild animals. Many animals were implicated in the crop losses, including elephants and gorillas, but rodents appeared to be the most destructive in terms of volume of losses.

A relatively new practice was establishment of traps around farming plots to kill the crop raiders, but this appeared to be dependent on individual efforts rather than communal activity. A common method was to build a combination of fence and trap around the field called osap, a traditional structure consisting of a 50-cm-high fence made from bamboo with small holes where traps are placed. Seventeen households described trapping of some sort with the materials for such traps being obtained from 
the forest. One household described the futility of such methods against larger animals like elephants and gorillas but it would appear that their greatest problem was with much smaller animals. Interestingly the nature of bushmeat hunting at Atom was described as changing due in part to the intensity of crop raiding. For example, one household stated: 'there has been a change in the type of hunting and traps because nowadays I do not hunt for commercial reasons, but to protect my crops' (Atom 09). The setting of traps was primarily a crop-protection measure, but the trapped animals were commonly used as a supplementary source of meat.

In Rwanda, the problem animals were buffalo, monkey and porcupines, entering farmland around the fringes of the Volcanoes National Park. This was a major concern in Masasa, especially, and there was a sense of injustice expressed by several households that they did not receive compensation from the park authorities for their losses. The issue of inadequate compensation schemes for crop losses and animal attacks is a recurrent theme for many communities living around protected areas (Nyhus et al. 2005). One household in Masasa had quite an interesting ecological perspective on why crop raiding was becoming an increasing problem. The interviewee noted that: 'In the 1970s our agriculture had a high yield even if there were animals coming from the park that were raiding our crops' (Masasa 12). He then continued to explain that, in his view, in 2003, the vegetation in the park started to change because of a change in conservation practice:

....before people were allowed to cut dry trees and bamboo, but when they stopped people from cutting those trees and bamboo, it destroyed the equilibrium that was set by the people. Dried bamboo when they fall on the ground do not allow other herbs and grasses to grow. This caused a shortage of grass for animals and they come out of the park and raid our crops. (Masasa 12).

This discussion of the conflict between local forests as a source of ecosystem services and a source of harm illustrates different dimensions of trade-offs. The main ecological dimension of the trade-off does not so much result from the protection of one service leading to reduction in another. Instead, it is a matter of coincident effects: where the provision of one set of beneficial services involves the production of at least one ecosystem 'disservice', namely harmful wildlife such as rodents. Several authors have recently drawn attention to the idea that the existence of positive services from ecosystem functioning logically also implies the existence of negative ecological impacts, at least for certain actors and interests (e.g. Few 2013; Lele 2013; Sandbrook and Burgess 2015). This trade-off connects with both social and spatial dimensions in that some households were more vulnerable to the disservices than others, because of the location of their fields and homes, and because some were more able to cope with the disservice (e.g. trapping animals) and even turn the rise in rodent populations into a service (e.g. food source). There was also a local-global dimension to this trade-off in that external national/global stakeholders enjoyed the benefits of forest protection without suffering from the associated disbenefits.

\section{Trade-off 2: forest coverage versus land for farming}

Some households in the study expressed a strong desire to see the forest preserved as much as possible, but, for most, a preservation ethic was replaced by perspectives that were much more utilitarian. For many the existence of the forest was not only a source of forest resources but an opportunity to access land. In Cameroon, 23 households indicated that they had increased their land size since household formation, and several openly explained that they had acquired new land by clearing the primary forest. In common with shifting cultivation practice, a few households explained that they were working land further from their homes because the productivity of the soil was better and they experienced fewer problems with crop diseases. There was a strong reaction from most interviewees to the idea of placing strict controls on this practice. The response of one household was:

We cannot create farms without cutting down trees. It will be very bad if it is forbidden. We will no more have food to eat. Talk to the forest exploiters; they are the problem. What can a poor farmer working with his hands do to this immense forest? (Djalobekue 06).

Not surprisingly, a hypothetical question on the possible reforestation of agricultural land posed to households in Cameroon provoked strongly negative responses from most households. In Equatorial Guinea the idea of controlling further deforestation in secondary forest land divided opinions evenly among interviewees, although several households stated that they already leave areas fallow for extended periods of time (2-10 years) or that they would expect to be compensated if they were not allowed to clear. A fairly positive response, however, was expressed about the idea of converting plots to agroforestry in the communities, with all households in Atom expressing support for the idea. But the strength of their underlying priority to rise out of poverty was paramount, and must be recognised. Direct questions about cash crops in the communities in both Cameroon and Equatorial Guinea led to virtually unanimous support for increasing production, on the ground that this would raise incomes, enabling them to 
improve their lives through the building of better homes, sending their children to school, and purchase of material goods.

In the case of the Rwanda communities, the land issue is quite different, because the national park is strictly protected and rural population density high. Those that were acquiring land were predominantly doing so through a formalised tenure system of buying land or inheritance of increasingly fragmented family plots. Households were therefore almost unanimously concerned about any potential expansion of the park and generally felt that even if compensation for land purchase were received, it would fall short of replacing the assets that the households currently possessed. Even a policy of reforestation on steeper slopes to protect against soil erosion raised major concerns about production losses.

The trade-off between managing lands for forest conservation versus farms was not only social but also ultimately an ecological one wherein the prioritisation of preserving biodiversity and regulating ecosystem services constrained the productive ecosystem service of generating subsistence and cash crops on farms. As previous work has found (e.g. Raudsepp-Hearne et al. 2010), this is a critical trade-off and one we consider central to the difficulties of achieving winwin solutions combining mitigation and adaptation. The reality in all our field sites is that economic development is clearly central to the ability to adapt to climate change. Agroforestry certainly appeared to hold promise and this was starting to be recognised by some villagers. But for the majority of villagers, economic development was seen to depend on farming, with strong emphasis placed on cash crops such as cocoa. This again demonstrates the strong spatial-temporal trade-offs involved in ecosystem management decisions, in that there are not currently any well-developed mechanisms in the case study sites for alleviating this trade-off between local, short-term development needs, and long-term global needs for mitigation.

\section{Trade-off 3: resource conservation versus access to resources}

Controls on the exploitation of forest resources can be a means to ensure they are sustainably managed as well as preserving ecosystem and biodiversity integrity. However, the sustainable management of resources is only meaningful to local people if they retain access to user rights in some sense (FAO 2014).

In Rwanda, for the communities around the Volcanoes National Park the tightening of restrictions and/or their enforcement generated livelihood impacts for some households. Change in access to resources was reported as a cost by 13 households interviewed. One villager described the impact:
During the past years when there was poverty, we entered into the forest for collecting bamboo and if these were sold we find some money to buy food. We put our beehives into the forest.... Nowadays, all these actions are not allowed to be made in the park. (Masasa 02).

Loss of the chance to collect firewood in the park was the most common complaint, voiced by 10 households, although there was a greater expression of acceptance of this situation than, for example, the impacts of crop consolidation policy. One household stated: 'we're affected but there's nothing to do, because they are the programs of our government for our common interests.' (Masasa13). Another householder described having to reduce the number of cattle he owned because, in combination with control on grazing within the park, the government implemented a law that all cattle be confined:

Our main activity was to raise cattle. We had 10 cows, 8 goats, 1 sheep and 12 rabbits. Our livestock used to graze in the park and we did not have a problem of feeding them. After, the government policy was to raise livestock in stables and to cultivate grass for them. As we did not have sufficient land, our livestock started to reduce in number (Masasa12).

In the sites in Equatorial Guinea and Cameroon, existing restrictions were much weaker and people's access to forest resources not strongly controlled. Interviewees were therefore asked to speculate how greater restrictions associated with a more rigorous forest conservation and management approach might affect them. The main concern raised in Equatorial Guinea was continued access to bushmeat. Households who spoke against controls on hunting stated that they depended heavily on meat for food and income, and were concerned that a prohibition would result in increased crop-raiding activities. However, on balance, slightly more households stated that they were in favour of hunting controls-most households indicated that they did not consume much meat or that they could simply purchase frozen goods instead. Some still wanted compensation for such a loss.

Interviewees in Cameroon were more solidly against a limitation on hunting, with 32 speaking against it and only five in favour. Reasons for opposing such a control included low levels of livestock in the village, bushmeat as a traditional source of nutrition, and loss of opportunity to sell the meat for income generation. Concern was also raised that increased timber concessions in the area would entail greater restrictions on access: 'If the concession is enlarged, we cannot enter everywhere we want to collect what we want' (Djalobekue 05). Two Baka households 
spoke explicitly about their fundamental relationship with the forest, and the cultural impact of being removed from the forest on their family and well-being. One simply stated: 'The forest is our god. The Baka is nothing without the forest. It represents everything for us' (Mang 20).

The case of the Baka provides us with an important reminder that socio-ecological trade-offs cannot all be understood in terms of economic values. The values expressed here by the traditionally forest-dwelling Baka are cultural and not commensurate with financial interests. This places additional constraints on the ability to find mechanisms that will alleviate trade-offs, seeing that financial compensation might fail to address the real sense of loss for some stakeholder groups.

\section{Trade-off 4: external intervention versus local ownership}

The final trade-off concerns management regimes and ownership. Strengthened forest management and conservation actions tend to entail greater degree of intervention from the state and non-governmental actors. The interviewees expressed concerns for the implications of ceding greater control over forest resources to external actors, a finding that mirrors that in a study of carbon sequestration projects across Africa by Jindal et al. (2008).

In the Cameroon sites, there was concern expressed especially over the potential expansion of forest concessions in the area, and the inability of villagers to enter forests that are being actively managed by the timber industry. Some anger was expressed about the power of logging companies to exclude people from forest land-set against a traditional system that allows people to gain ownership of the forest land that they clear and pass it down to future generations. There were allegations of corruption by the village leadership in relation both to the actions of timber companies and the government. One household in Mang stated:

The leaders of the village did not know how to defend our interest in front of the government and the whites $^{2}$ who are exploiting our forests. They were given money secretly for them to allow the cutting of trees around us. Now we have no wood for our own construction (Mang 14).

In Equatorial Guinea, households were very positive about the potential for legalisation of community-managed forests in their area. The predominant reason for this was utilitarian in that it was seen as a means of preventing logging companies from claiming forest land without

\footnotetext{
2 'Whites' here refers to outsiders and not necessarily to a skin colour.
}

providing compensation to local people. However, even the management of community forests established around the villages in Cameroon raised questions around ownership and transparency. More than half of the interviewed households (22) claimed to have no knowledge of the existence of community forests, bringing into question the extent to which their use and management is broadly community-based. Another 3-4 households in each village described active exclusion from participation in the community forest management.

In Rwanda, concerns over external management of reforested land were a major issue for villagers. It appeared that private woodlots in both villages were subject to government control over felling, with permits required from local government. Kamiro interviewees described the process as cumbersome and indicated that a harvest of timber in one woodlot impacted on the likelihood of gaining permission to harvest in a neighbouring lot that might be owned by a different individual. If there were to be reforestation programmes on steep slopes, people who were in favour of this were most concerned as to whether or not they would in fact be the owners of such plantations (as opposed to the government). In the words of one householder: 'If the program obliges us to plant trees in our lands and become owners of them, we will accept but if those trees become the property of the government they will affect us negatively' (Kamiro 03). The same concerns over ownership rights were raised even when interviewees discussed the potential for development of agroforestry in the area. Thus, as we have seen with previous trade-offs, the development of mechanisms to reconcile the interests of adaptation and mitigation cannot be reduced only to financial planning, such as projected revenues from agroforestry.

More broadly, policy intervention on land management in Rwanda has generated further examples of reduced local control over resource use (Dawson et al. 2016). Under the Crop Intensification Program (MINAGRI 2008), locations are typically expected to specialise in no more than three out of the seven government priority crops, with even more severe constraints on what individual farmers are allowed to grow. Farmers complained that this undermined the traditional systems of polyculture that have evolved locally as an adaptation to complex environmental conditions. One householder from Kamiro village explained that in the past if a harvest such as maize was damaged by weather conditions then the household could usually still rely on the yield from other crops. Another from the same village added:

We have to accept it, but the remaining problem is when the authorities enforce the community to plant one crop. This crop may not grow well and causes some problems including hunger (Kamiro 09).' 


\section{Conclusion}

Most of the authors writing about the potential for synergy recognise that achieving mitigation and adaptation gains presents major challenges (e.g. Locatelli et al. 2010; Robledo et al. 2012; Sonwa et al. 2012). Some see a need to unblock the potential through awareness raising and improved governance. But others underline that we also need to understand more about the role forests can play in reducing vulnerability and promoting adaptation. We argue that this must mean taking a step back from conceptual argument and using empirical research to critically assess the assumptions on which ideas of synergy are founded.

The exploratory case studies discussed in this paper, though limited in geographical scope, nevertheless provide illustrative evidence to inform discussions on the role of forests in fostering adaptation for the poor while simultaneously addressing mitigation. Across the study villages in three countries, there were commonly held perceptions that climatic stresses impacted on livelihoods, focussing especially on erratic rainfall patterns and increasing unpredictability of the seasons. Whether the perceived climatic variations constituted a genuine climate change trend is open to question, but it is key to note that climatic stress was perceived to affect the productivity and susceptibility to disease of crops. These impacts, compounded by other environmental and socio-economic stresses, in turn impacted on lives, livelihoods and well-being among the households we interviewed.

Villagers also described positive benefit from the existence of forests and forest resources in their surrounding environment. Many villagers directly accessed water, firewood, bamboo, bushmeat, fruits, medicinal plants and other NTFPs from the forests. Forests also constituted a source of land for farming and an opportunity for isolation of animals during epidemics, while tree planting on farms in the study sites variously provided firewood, stabilisation of soils and protection from extreme events. On the face of it, then, in these villages we have a situation in which people were likely to face ongoing climatic stresses and in which forested landscapes were likely to provide continuing forms of hazard protection, sources of income and subsistence and alternative sources of resources.

However, it was also clear that people held complex, and often ambiguous, perspectives on forests, and that the existence of forest and of forest conservation and management practices were also perceived to have negative implications for livelihoods and resilience. Bringing together evidence from the 126 interviews in different zones of the Congo Basin, and across different management regimes (including protected areas, community forests, logging concessions and more open-access forests) we can identify four main trade-offs expressed within people's perspectives. First, while the proximity of the forest confers advantages in terms of accessibility to resources, it also constitutes a threat to livelihoods in terms of crop raiding by wild animals. Second, measures to conserve or extend forest coverage increase abundance of forest resources but constrain availability of land for farming. Third, conservation restrictions can preserve ecosystem integrity but can also restrict the rights of local people to access the resources that might strengthen resilience. Fourth, if strengthened forest management implies greater external intervention then it may lead to a loss of local power and control over forest resources.

The negative implications expressed by villagers will come as no surprise to many working in forest management, and constitute issues that can to some extent be ameliorated through more people-centred approaches to ecosystem management. However, they do bring sharply into relief the potential for assumptions about synergistic mitigation-adaptation gains to be unravelled by on-theground socio-environmental realities. Part of this disconnect may come down to a focus on 'forest-dependent communities' in discussions of synergy: 'dependency' by definition implies that conserving forests is supportive for livelihoods, because it conserves ecosystem services for livelihoods. This, conceptually, paves the way for the idea of ecosystem-based adaptation. But it is evident that many, probably most populations, living in close association with forests, do not have a simple form of dependency on forest resources: most such people have access to alternative resource options and differing interests in management of the forests that complicate perspectives and priorities. The idea that their resilience will be strengthened by a forestbased adaptation cannot necessarily be assumed.

Indeed, where broad-based adaptation gains are more likely to be demonstrable is in situations where a compromise between optimal carbon sequestration (and/or biodiversity conservation) and livelihood resilience is inherent in their design. Such attempts at achieving synergies will tend to involve interventions that seek complex forest composition (rather than carbon monocultures) and ones that adopt landscape scale planning to include relationships between forests and agriculture (D'Amato et al. 2011; Harvey et al. 2014).

The findings of the research highlight the need to understand both the limits of synergy, and the constraints and trade-offs for rural livelihoods that may be associated with a forest conservation agenda driven by the additional impetus of carbon sequestration. The search for synergy may be conceptually laudable, but if forest management actions do not take account of on-the-ground contexts of constraints and social trade-offs then the result of those 
actions risks undermining wider livelihood resilience and ultimately the chances for adaptation of those most vulnerable to climate change.

Acknowledgements The research was part of a wider collaborative project, Climate Change and Forests in the Congo Basin (COBAM) led by Centre for International Forestry Research (CIFOR). We are very grateful to all those who have helped to make this study possible. In Rwanda, the work was facilitated by ARECO, and in particular: Dancille Mukakamari, Jean-Pierre Mugabo, Emmanuel Dufitumukza. Field data collection was greatly assisted by Assumpta Uzamukunda and Laura Rurangwe. In Cameroon, the work was supported by CIFOR (Yaounde), in particular Anne-Marie Tiani, Charlotte Pavageau and Flore Ndong; by Stockholm Environment Institute (Oxford), in particular Tahia Devisscher and by ROSE, in particular Gerard Sindemo. Field assistance was provided by Chrislain Kenfack and Sylvie Asso. In Equatorial Guinea the work was supported by INDEFOR, in particular Fidel Esono Mba, Diosdado Obiang Mbomio and Juan Abeso; and by SEI, Monica Coll Besa. Field assistance was provided by Angeles Mang Eyene and Alfonso Mikue. COBAM is supported through an African Development Bank grant to the Economic Community of Central African States for financing the Congo Basin Ecosystems Conservation Support Program.

Open Access This article is distributed under the terms of the Creative Commons Attribution 4.0 International License (http://crea tivecommons.org/licenses/by/4.0/), which permits unrestricted use, distribution, and reproduction in any medium, provided you give appropriate credit to the original author(s) and the source, provide a link to the Creative Commons license, and indicate if changes were made.

\section{References}

Anderson K (2015) Duality in climate science. Nat Geosci 8(12):898-900. doi:10.1038/ngeo2559

Bele MY, Tiani AM, Somorin OA, Sonwa DJ (2013) Exploring vulnerability and adaptation to climate change of communities in the forest zone of Cameroon. Clim Change 119:875-889. doi:10. 1007/s10584-013-0738-z

Bennett EM, Peterson GD, Gordon LJ (2009) Understanding relationships among multiple ecosystem services. Ecol Lett 12:1394-1404. doi:10.1111/j.1461-0248.2009.01387.x

Cardinale BJ, Duffy JE, Gonzalez A, Hooper DU, Perrings C, Venail P, Narwani A, Mace GM, Tilman D, Wardle DA, Kinzig AP (2012) Biodiversity loss and its impact on humanity. Nature 486(7401):59-67. doi:10.1038/nature11148

D'Amato AW, Bradford JB, Fraver S, Palik BJ (2011) Forest management for mitigation and adaptation to climate change: insights from long-term silviculture experiments. For Ecol Manage 262:803-816. doi:10.1016/j.foreco.2011.05.014

Daw T, Coulthard S, Cheung W, Brown K, Abungeg C, Galafassia D, Petersona GD, McClanahanh TR, Omukotoi JO, Munyij L (2015) Evaluating taboo trade-offs in ecosystem services and human wellbeing. PNAS 112:6949-6954. doi:10.1073/pnas.1414900112

Dawson N, Martin A, Sikor T (2016) Green revolution in sub-Saharan Africa: implications of imposed innovation for the wellbeing of rural smallholders. World Dev 78:204-218. doi:10.1016/j. worlddev.2015.10.008

Devisscher T, Bharwani S, Tiani AM, Pavageau C, Kwack NE, Taylor R (2013) Current vulnerability in the Tri-National de la Sangha landscape, Cameroon. Working paper 107, CIFOR, Bogor, Indonesia
Dkamela GP (2011) Le contexte de la REDD+ au Cameroun: causes, agents et institutions. Papier Occasionnel 57. CIFOR, Bogor, Indonesia

FAO (2014) State of the World's forests: enhancing the socioeconomic benefits from forests. Food and Agriculture Organization of the United Nations, Rome

Few R (2013) Health, environment and the ecosystem services framework: a justice critique. In: Sikor $\mathrm{T}$ (ed) The justices and injustices of ecosystem services. Earthscan, London, pp 140-160

Few R, Gross-Camp ND, Martin A (2014) Vulnerability, adaptation and mitigation in the forests of the Congo Basin: a critical investigation. Working Paper 48, DEV Working Paper Series, The School of International Development, University of East Anglia, UK

Frame DJ, Macey AH, Allen MR (2014) Cumulative emissions and climate policy. Nat Geosci 7:692-693. doi:10.1038/ngeo2254

Gebauer C, Doevenspeck M (2015) Adaptation to climate change and resettlement in Rwanda. Area 47(1):97-104. doi:10.1111/area. 12168

GoEG (Government of Equatorial Guinea) (1997a) Ley n 1/1997, de fecha 18 de febrero, sobre el uso y manejo de los bosques. Gobierno de Guinea Ecuatorial, Malabo, Equatorial Guinea

GoEG (Government of Equatorial Guinea) (1997b) Decreto $\mathrm{n}^{\circ}$ 97/1.997, de fecha 12 de Agosto, por el que se aprueba el Reglamento de Aplicaci6n de la Ley Sobre el Uso y Manejo de los Bosques. Gobierno de Guinea Ecuatorial, Malabo, Equatorial Guinea: $121-138$

Harris NL, Brown S, Hagen SC, Saatchi SS, Petrova S, Salas W, Hansen MC, Potapov PV, Lotsch A (2012) Baseline map of carbon emissions from deforestation in tropical regions. Science 336:1573-1576. doi:10.1126/science. 1217962

Harvey CA, Chacón M, Donatti CI, Garen E, Hannah L, Andrade A, Bede L, Brown D, Calle A, Chará J, Clement C, Gray E, Hoang MH, Minang P, Rodríguez AM, Seeberg-Elverfeldt C, Semroc B, Shames S, Smukler S, Somarriba E (2014) Climate-smart landscapes: opportunities and challenges for integrating adaptation and mitigation in tropical agriculture. Conserv Lett 7:77-90. doi:10.1111/conl.12066

Howe C, Suich H, Vira B, Mace GM (2009) Creating win-wins from trade-offs? Ecosystem services for human well-being: a metaanalysis of ecosystem service trade-offs and synergies in the real world. Glob Environ Change 28:263-275. doi:10.1016/j.gloenv cha.2014.07.005

Ibarra JT, Barreau A, Campo CD, Camacho CI, Martin G, McCandless S (2011) When formal and market-based conservation mechanisms disrupt food sovereignty: impacts of community conservation and payments for environmental services on an indigenous community of Oaxaca, Mexico. Int For Rev 13:318-337. doi:10.1505/ifor.13.3.318

Jindal R, Swallow B, Kerr J (2008) Forestry-based carbon sequestration projects in Africa: potential benefits and challenges. Nat Resour Forum 32:116-130. doi:10.1111/j.1477-8947.2008.00176.x

Kongsager R, Corbera E (2015) Linking mitigation and adaptation in carbon forestry projects: evidence from Belize. World Dev 76:132-146. doi:10.1016/j.worlddev.2015.07.00

Lele S (2013) Environmentalisms, justices and the limits of ecosystem services frameworks. In: Sikor T (ed) The justices and injustices of ecosystem services. Earthscan, London, pp 119-139

Locatelli B, Brockhaus M, Buck A, Thompson I (2010) Forests and adaptation to climate change: challenges and opportunities. In: Mery G, Katila P, Galloway G, Alfaro RI, Kanninen M, Lobovikov M, Varjo J (eds) Forests and society—responding to global drivers of change, vol 25. IUFRO World Series, Vienna, pp 21-42

Locatelli B, Pavageau C, Pramova E, Di Gregorio M (2015) Integrating climate change mitigation and adaptation in agriculture and forestry: opportunities and trade-offs. Wiley Interdiscip Rev Clim Change 6(6):585-598. doi:10.1002/wcc.357 
McShane TO, Hirsch PD, Trung TC, Songorwa AN, Kinzig A, Monteferri B, Mutekanga D, Van Thang H, Dammert JL, PulgarVidal M, Welch-Devine M (2011) Hard choices: making tradeoffs between biodiversity conservation and human well-being. Biol Conserv 144(3):966-972. doi:10.1016/j.biocon.2010.04.038

MINAGRI (2008) Strategic plan for the transformation of agriculture in Rwanda (SPAT II). Final report. Rwandan Ministry of Agriculture, Kigali

Mugnier A, Martinez-Plaza S (2009) The forests of Equatorial Guinea. In: de Wasseige C, Devers D, de Marcken P, Eba'a Atyi R, Nasi R, Mayaux P (eds) The forests of the Congo Basinstate of the forest. Publications Office of the European Union, Luxembourg

Nelson DR (2011) Adaptation and resilience: responding to a changing climate. Wiley Interdiscip Rev Clim Change 2(1):113-120. doi:10.1002/wcc.91

Nguema J, Pavageau C (2013) Adaptación y atenuación en Guinea Ecuatorial: actores y procesos políticos. CIFOR, Bogor

Nkem J, Kalame FB, Idinoba M, Somorin OA, Ndoye P, Awono A (2010) Shaping forest safety nets with markets: adaptation to climate change under changing roles of tropical forests in Congo Basin. Environ Sci Policy 13:498-508. doi:10.1016/j.envsci. 2010.06.004

Nkem JN, Somorin OA, Jum C, Idinoba M, Bele MY, Sonwan DJ (2013) Profiling climate change vulnerability of forest indigenous communities in the Congo Basin. Mitig Adapt Strateg Glob Change 18:513-533. doi:10.1007/s11027-012-9372-8

Nyhus PJ, Osofsky SA, Ferraro P, Madden F, Fischer H (2005) Bearing the costs of human-wildlife conflict: the challenges of compensation schemes. In: Woodroffe R, Thirgood S, Rabinowitz A (eds) People and wildlife, conflict or co-existence? Cambridge University Press, Cambridge, pp 107-121

Parrotta JA, Wildburger C, Mansourian S (2012) Understanding relationships between biodiversity, carbon, forests and people: the key to achieving REDD+ objectives. International Union of Forest Research Organizations (IUFRO)

Pavageau C, Coll Besa M, Morchain D (2013a) Current vulnerability in the Monte Alen-Monts de Cristal landscape, Equatorial Guinea. CIFOR, Bogor

Pavageau C, Butterfield R, Tiani AM (2013b) Current vulnerability in the Virunga landscape, Rwanda. CIFOR, Bogor

Raudsepp-Hearne C, Peterson GD, Bennett EM (2010) Ecosystem service bundles for analyzing tradeoffs in diverse landscapes. Proc Natl Acad Sci USA 107:5242-5247. doi:10.1073/pnas. 0907284107

Robledo C, Clot N, Hammill A, Riche B (2012) The role of forest ecosystems in community-based coping strategies to climate hazards: three examples from rural areas in Africa. For Policy Econ 24:20-28. doi:10.1016/j.forpol.2011.04.006
Rodríguez JPT, Beard D, Bennett EM, Cumming GS, Cork S, Agard J, Dobson AP, Peterson GD (2006) Trade-offs across space, time, and ecosystem services. Ecol Soc 11:28

RoR (Republic of Rwanda) (2006) Programmes d'Action Nationaux d'Adaptation aux Changements Climatiques. Ministere des Terres, de l'environnement, des Forets, de l'Eau et des Mines, Republique du Rwanda, Kigali

RoR (Republic of Rwanda) (2011) Green growth and climate resilience: national strategy for climate change and low carbon development. Republic of Rwanda, Kigali

Sandbrook CG, Burgess N (2015) Biodiversity and ecosystem services: not all positive. Ecosyst Servi 12:29. doi:10.1016/j. ecoser.2014.12.006

Saxena A, Guneralp B, Bailis R, Yohe G, Oliver C (2016) Evaluating the resilience of forest dependent communities in Central India by combining the sustainable livelihoods framework and the cross scale resilience analysis. Curr Sci 110(7):1195-1207

Sikor T (ed) (2013) The justices and injustices of ecosystem services. Earthscan, London

Somorin OA, Visseren-Hamakers IJ, Arts B, Tiani AM, Sonwa DJ (2016) Integration through interaction? Synergy between adaptation and mitigation (REDD+) in Cameroon. Environ Plan C Gov Policy 34(3):415-432. doi:10.1177/0263774X16645341

Sonwa DJ, Somorin OA, Jum C, Bele MY, Nkem J (2012) Vulnerability, forest-related sectors and climate change adaptation: the case of Cameroon. For Policy Econ 23:1-9. doi:10. 1016/j.forpol.2012.06.009

Stern N (ed) (2007) The economics of climate change: the Stern review. Cambridge University Press, Cambridge

Tol RSJ (2005) Adaptation and mitigation: trade-offs in substance and methods. Environ Sci Policy 8:572-578. doi:10.1016/j.envsci. 2005.06.011

Vedwan N, Rhoades RE (2001) Climate change in the Western Himalayas of India: a study of local perception and response. Clim Res 19:109-117. doi:10.3354/cr019109

Vira B, Agarwal B, Jamnadass RH, Kleinschmit D, McMullin S, Mansourian S, Neufeldt H, Parrotta JA, Sunderland TCH, Wildburger C (2015) Introduction: forests, trees and landscapes for food security and nutrition. IUFRO World Series 33. International Union of Forest Research Organizations (IUFRO)

Wahlstrom M (2015) The critical role of trees and forests in disaster risk reduction. Unasylva 66(1-2):3-5

Wunder S, Borner J, Shively G, Wyman M (2014) Safety nets, gap filling and forests: a global-comparative perspective. World Dev 64(Supp 1):S29-S42. doi:10.1016/j.worlddev.2014.03.005 